\title{
Cute and Cool in Contemporary Japanese Visual Arts
}

\author{
GUNHILD BORGGREEN
}

\begin{abstract}
Under the headline of 'Japan Cool', popular culture from Japan has gained a significant role in the global market within the last decade. One of the concepts related to 'Japan Cool' is kawaii, meaning cute and sweet, both as a style and a lifestyle. Kawaii can be seen as visual trademarks in fashion, manga, animé, and many other parts of popular culture, as well as in visual arts by neo-pop artists such as Murakami Takashi and his associates. However, kawaii as a critical concept, has been flourishing in Japan since the 1980s, and has been the topic of sociological research that stresses the subversive and critical dimensions of the word. This article investigates how artworks can offer an ethnographic account of kawaii as a sign of ambiguity and thus signify important social currents in Japanese youth culture in the decade before 'soft power' became the agenda for official Japan.
\end{abstract}

Keywords: Japan, visual arts, cool, cute, performance, 'soft power'

\section{Introduction}

In February 2009, Japan's Ministry of Foreign Affairs announced three new ambassadors for Japan. Introduced as kawaii taishi, 'cute ambassadors', three young female fashion icons, Aoki Misako, ${ }^{1}$ Kimura Yû and Fujioka Shizuka, are now representing Japan as 'Trend Communicators of Japanese Pop Culture' (Ministry of Foreign Affairs 2009). News media around the globe reported on this event and many images of the new pop culture ambassadors have circulated worldwide since. Figure 1 shows the official announcement ceremony in Tokyo. The three cute ambassadors have been busy travelling the world to engage in events related to Japanese popular culture, such as the Japan Expo in Paris in July 2009, and in November of the same year, the XV Salón del Manga in Barcelona and a 'Lolita's Parade' in Rio de Janeiro. Thousands of fans of Japanese sweet and cute popular culture gather at these events to cheer their idols and be part of the activities by dressing up in the same style of clothes or participating in amateur catwalk displays. The 'cute 
ambassadors' attract a great deal of attention and thousands of fans around the world have expressed their fascination, some on YouTube blogs. Shatteredlolita exclaims, 'you just have to love the gothic lolita fashion' (shatteredlolita 2009). Another fan declared her devotion to one of the 'cute ambassadors', Aoki Misako: 'Misako!!!!!!!!!!!!!!!!!!!! Is my idol and is the cutest thing in the world. I have seen her alive and she is even[more] beautiful than [in] pictures and videos. Misako keep it up!' (MadameGinerva 2009).

In contrast to the thousands of fans among young people, the appointment of three 'cute ambassadors' appears to have been received

FIGURE 1: Three 'cute ambassadors' assigned by Japan's Ministry of Foreign Affairs, Feb. 2009.

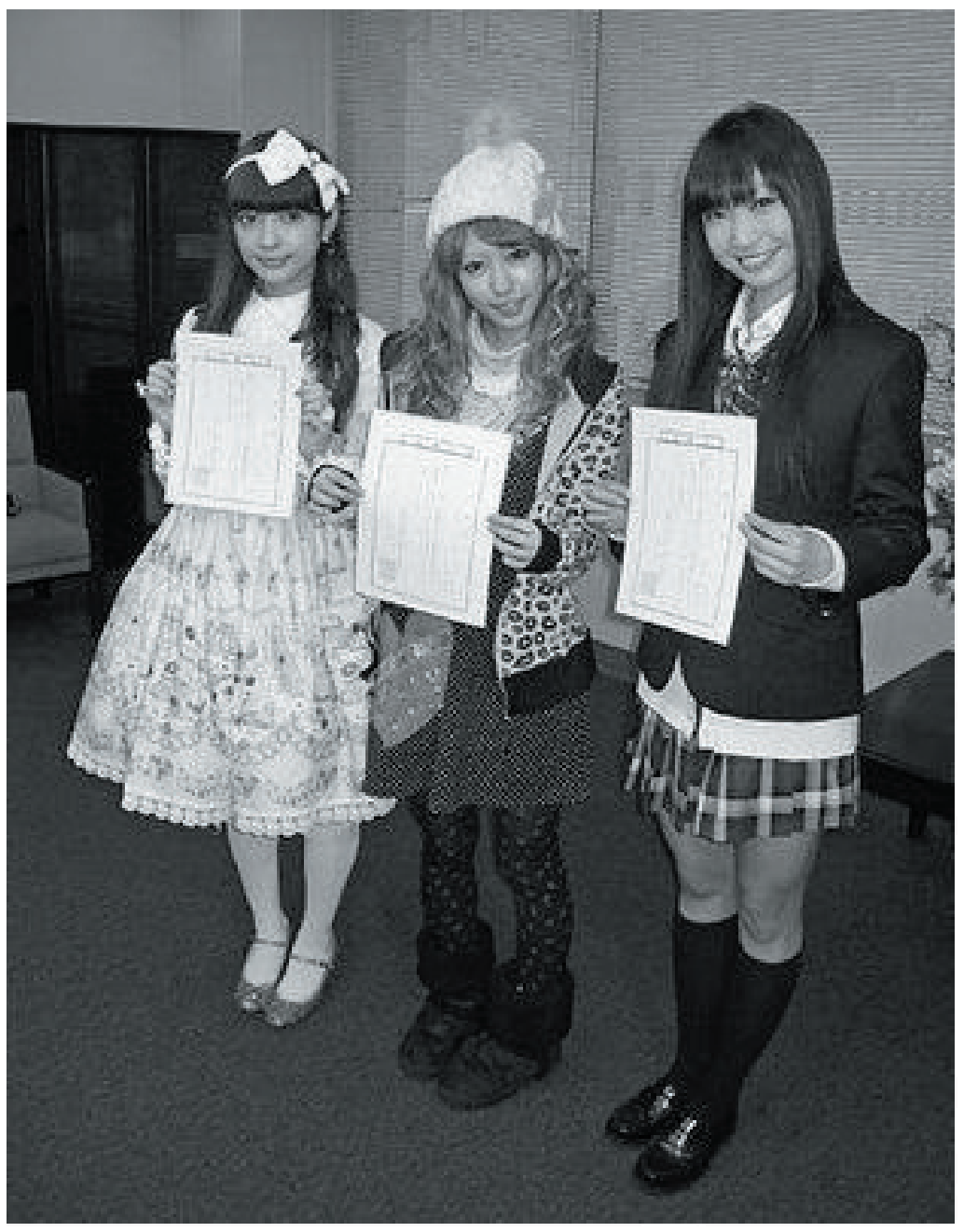


by Western media in general with equal amounts of blunt ridicule and dumbfounded head-shaking. One blogger commented: 'Is this serious? It seems so and still can't find my jaw somewhere around the floor' (Toonleap 2009). The announcement was mainly dismissed as either the Japanese government's total disregard of the fine art of diplomacy, or as yet more proof of the Japanese government's complete surrender to the logics of soft power promotion of popular culture to boost Japan's gross national product.

The main concept in this performance of international diplomacy is the word kawaii. Kawaii translates as sweet, cute, innocent, pure, gentle, vulnerable, weak; but the concept also is associated with something pathetic, poor or pitiable, as in the word kawaisô (poor, miserable) (Kinsella 1995: 220ff.). In a global context, the term kawaii has come to signify a specific 'Japanese' kind of cute style found in various aspects of popular culture, such as in fashion, design, manga (comic strip stories), animé (animated films), computer games, gadgets, and many other domains. Kawaii can be said to represent a dimension of contemporary aesthetics in Japanese culture that interacts with popular culture and the dynamics of everyday life. The concept of kawaii has also been prominent in the field of visual arts from Japan. A number of recent art exhibitions and publications, both in and outside Japan, have focused particularly on the visual and stylistic aspects of cute and colourful expressions found in many of the works by neo-pop artists such as Murakami Takashi, Nara Yoshitomo and the artist known as Mr., along with younger generations of female protégés such as Takano Aya, Ban Chinatsu and Aoshima Chiho. ${ }^{2}$ This seems to suggest that visual arts are being identified and promoted as part of a larger popular culture framework, and that visual arts, too, are being included as part of Japan's newly discovered soft power resources.

What does this inclusion in the soft power framework mean for the visual arts in Japan? If cuteness in visual arts is seen as representing 'Japaneseness', then how can visual art provide an insight into the cultural dynamics of kawaii within the Japanese society? In order to investigate these questions in detail, I will start by looking into the discourses of 'Japaneseness' in relation to popular culture and the awareness of soft power potential to argue that a change in the status of kawaii took place around the turn of the millennium. In my analysis of works by two Japanese contemporary artists, Nishiyama Minako and Sawada Tomoko, I will locate the concept of kawaii in popular culture as well as in visual arts, and propose that kawaii in visual arts provided a framework for 
cultural critique during the 1990s, before kawaii became a soft power cultural export. By including theories of performance, I will argue that the artworks by Nishiyama and Sawada contain significant performative gestures that create an awareness of the participatory elements in kawaii popular culture and the potential for social and political change. I conclude that the concept of kawaii has potential for powerful social subversion, and that this may be a reason for official Japanese institutions such as the Ministry of Foreign Affairs to endorse only a certain type of kawaii as an image of Japanese cultural identity.

\section{Cultural Odour}

The intense export of cute and sweet aspects of Japanese popular culture as seen in the 'cute ambassadors' incident is not new. Pop culture icons such as Astro Boy and Hello Kitty have been well known in the United States and most other parts of the world for the last 30 years or more. Other more recent Japanese products related to figures such as Pokemon or Super Mario Brothers are also widespread on a global market. During the early 1990s, however, most foreign consumers would not relate such products to Japan, as the characters and the narratives in most cases remain what cultural critic Iwabuchi Kôichi identifies as 'odourless', 'products which...do not immediately conjure images of the country of origin in the minds of consumers' (Iwabuchi 1998: 165). According to Iwabuchi, the explicit lack of nationality (mu-kokuseki) in cultural products made in Japan also implies an erasure of racial or ethnic characteristics - a trend that is particularly dominant in the area of mang $a$ and animation film, where producers and animation directors in many cases draw characters modelled on Caucasian types (Iwabuchi 1998: 167). This can be seen as an example of 'glocalisation', a term invented in Japan and, according to Roland Robertson, closely related to the term 'micromarketing', which signifies companies' attempts to create standardized global markets while at the same time being sensitive to local markets and differentiated consumer segments (Robertson 1997: 28). As Iwabuchi notes in his extensive study from 2002 of the globalization of Japanese culture, if the 'Japaneseness' of Japanese animation derives from its erasure of physical signs of Japaneseness, then Western audiences have come to appreciate 'an animated, race-less and culture-less, virtual version of "Japan" ' (Iwabuchi 2002: 33). Iwabuchi argues that although there may be a fascination, and even an influence from Japanese pop culture products in the West, such a consumption 
is a 'monological illusion' because it is not associated with particular or tangible 'Japanese' lifestyles, and it lacks the full understanding of the socio-cultural context in which the artefacts are being produced (Iwabuchi 2002: 34).

\section{Gross National Cool}

The notion of cultural modesty in Japan was altered at the beginning of the twenty-first century. These days, most Japanese cultural exports are branded as 'made in Japan', especially after 2002, when the Canadian journalist Douglas McGray published an article in the journal Foreign Policy with the title 'Japan's Gross National Cool'. Punning on the term gross national product as an indicator of a country's total income, McGray launched the concept 'gross national cool'. With this concept, McGray argues that Japan is reinventing its superpower status by means of popular culture, and that the impact of Japanese culture on a global scale has become more powerful than Japanese economic influence had been in the 1980s (McGray 2002: 47). Listing a whole range of cultural items such as manga, animé, games, fashion, food and pop music, McGray points out that Japanese products have increasingly become distinctly 'Japanese' when marketed in the West. McGray refers to Joseph S. Nye, Jr.'s concept of 'soft power' to understand the dynamics of Japanese popular culture, and concludes that Japan, along with only a few other nations, has understood how to combine a 'flexible, absorptive, crowd-pleasing, shared culture' with a domestic culture, and taking advantage of this balance has created a 'mighty engine of national cool' (McGray 2002: 53). McGray's article became quite influential in Japan and elsewhere after 2002; the article has been translated and reprinted in other publications, numerous references have been made to McGray's concept of 'gross national cool', and McGray himself was invited to Japan and elsewhere to lecture on his prophecy about the future of Japan's cultural exports. The popularity of McGray and his article is no doubt related to the lure of 'soft power', as if McGray's identification of Japan's gross national cool was a recipe for becoming attractive through cultural power.

But being cool is not the same as having 'soft power'. As Anne Allison points out, because of the strong elements of mu-kokuseki (without nationality), Japanese popular culture products may be yearned for everywhere around the globe, but for the same reason, the products also lack a firm anchorage in the actual culture itself (Allison 2008:105). 
While Allison does not specifically argue against McGray's interpretation of the direct link between 'Japanese cool' and 'soft power', she suggests that new models of global imagination have developed in which Japanese cool, is attractive, but not one that generates an attraction for the actual culture of the producing country. Instead, Allison argues, Japan produces fantasy-ware: 'goods that inspire an imaginary space at once foreign and familiar and a subjectivity of continual flux and global mobility, forever moving into and out of new planes, powers, terrains, and relations' (Allison 2008: 107). Thus, the cultural influence attributed to kawaii or other Japanese concepts does not necessarily lead to an increase in the 'soft power' value of Japan's gross national cool, but rather points out the power of mobile imagination that may end up defying cultural hegemony and offer decentred and globalized exchange.

\section{Cool Contemporary Art}

Contemporary Japanese art has played a significant role in this attempt to market Japan as a distinct cultural brand, and 'cool' has been the main concept in promoting a neo-pop style in visual arts that reflects the increasing attention to Japanese popular culture from abroad. In 2001, the exhibition entitled Superflat, which was curated by the Japanese neo-pop artist Murakami Takashi, toured the United States. At that time, Murakami was already well known on the New York art scene for his manga-like character Mr. DOB, as well as for his collaboration with the international fashion company Louis Vuitton. The idea of visual art as part of a new source of soft power for Japanese culture has been widespread within Japan as well. In 2004, Japanese art critic Yamaguchi Yumi published a book in Japanese entitled Cool Japan. Shissô suru Nihon gendai aato (Cool Japan. The exploding Japanese contemporary art), in which Yamaguchi refers explicitly to Douglas McGray's article. And indeed, McGray himself appears in the publication in an interview with Yamaguchi about art and other aspects of Japanese popular culture. When asked explicitly about Murakami Takashi, McGray mentions Murakami's success in the United States as an important phenomenon, and argues that the circulation of Murakami's exhibitions and the translation of his essays has generated a deeper understanding of Japanese art in general in the US.

The block-buster exhibition, Little Boy. The Arts of Japan's Exploding Subculture, was shown at the Japan Society in New York in 2005 as the third and last of his Superflat exhibition series. Curated by Murakami, the exhibition featured a number of objects related to popular culture as 
well as artworks from Japan's post-war period, providing a framework for the mutual influence between cultural patterns on a broader scale and specific artworks as a reflection of such trends. Striking a critical note towards the American influence in post-war Japanese culture, the Little Boy exhibition aimed at emphasizing traits related to unique aspects of Japanese popular culture, especially the concepts of otaku (nerd culture) and kawaii (cute) (Murakami 2005). The exposure of Murakami's works in New York, McGray continues, has prompted a wave of 'post-Murakami' artists who wish to repeat his economic success, and thus the number of contemporary Japanese artworks on the New York art scene and the amount of money exchanged in this respect has increased due to the huge attention given to Japanese art (Yamaguchi 2004: 46). What is lacking in Yamaguchi's and McGray's admiration for the Superflat concept, however, is the search for a criticality that embodies much international contemporary art, and which is usually seen by art critics and curators of contemporary art to be a sign of quality. Since many of Murakami's art products become mass produced and turn into pop culture artefacts, the distinction between artwork and pop culture becomes blurred. Even Murakami himself admits that it may be harmful for his image as an artist that many critics in the West regard his art as too commercial (Frederick 2003: 60-61).

\section{Kawaii in Visual Arts}

The concept of kawaii in Japanese visual art, however, is not a recent phenomenon. During the 1990s kawaii became significant as a discursive element within visual arts in Japan. In the beginning, kawaii in visual arts was particularly connected to the emergence of a number of young female artists in the mid-1980s, the so-called 'Super girls in art,' a concept coined by Bijutsu techô (Art Notes), an influential art magazine in Japan. Under the headline Bijutsu no chôshôjo-tachi (Super girls in art), the August issue of 1986 featured a number of Japanese female artists, most of them from the younger generation. Artists' profiles and feature articles emphasized new styles and expressions connected with female artists, and general traits pointed forward to some of the stylistic characteristics of kawaii in visual art: young female artists, it was claimed, often include objects related to household goods and consumer products as well as aspects of fashion and ethnic art (Enomoto and Matsuoka 1986). These new modes identified by a leading art magazine in Japan appear to rely on some essential 'feminine' qualities rooted in biological determinism. 
The emphasis on women's art being especially bright and colourful and connected to consumer products established a discursive link between certain tendencies within visual arts to the way in which kawaii historically has been connected to shôjo, or girls' culture. Young female artists in Japan were seemingly being empowered by the label 'super', but they were also still named 'girls'. Taking the low representation of female artists in the Japanese art world in the mid-1980s into consideration, the special issue on 'Super girls in art' likely presented a dilemma for some of the artists involved. On one hand, the attention from a leading art magazine such as Bijutsu techô must have been helpful in promotion and exposure, while at the same time many artists probably did not recognize themselves within these limited descriptions of shôjo art.

\section{Kawaii as Critique}

There were critical voices against the unconditional praise of 'Super girl' art shown in Bijutsu techô and visualized in many art exhibitions and gallery displays in the late 1980s and early 1990s. In 1992, art critic Sawaragi Noi, for example, wrote about the kawaii phenomenon in art in another article in the same magazine (Sawaragi 1992). Sawaragi notes that although cute-looking objects exist in other cultures as well, no other country has been as full of kawaii mono (cute things) as Japan. The kawaii tendency has found its way into the art scene, particularly in the works by young female artists, who, according to Sawaragi, seem to have been moving their own rooms into art galleries when they decorate the exhibit walls with pastel colours and soft toys. Sawaragi points out that foreign art critics have observed the kawaii phenomenon in the Japanese society at large, but he regrets that kawaii art is promoted only as yet another layer of the already existing Orientalist perceptions of Japanese art (Sawaragi 1992: 92).

Kawaii as concept in the art world was not attributed only to young female artists in the 1990s. Visual elements of cuteness were also associated with a number of young male artists, including Tarô Chiezô, Itô Gabin, Nakahara Kôdai and Murakami Takashi. These artists represented a generation that grew up during the 1970s and 1980s, when economic growth prevailed. A gap emerged between the post-war youth and their parents' generation, and a generational conflict was reflected, for example, in a concept such as shinjinrui, 'the new human type' or 'the new breed'. The term was invented in the mid-1980s by the sociologist Nakano Osamu, who described this new generation as 
'narcissistic' and said they 'often exhibit autistic symptoms' (Nakano 1988: 12). The shinjinrui artists were seen as subverting the concept of adulthood by maintaining a youthful lifestyle and appropriating cute and childlike traits as critical elements in their artworks. American art critic Alexander Munroe, for example, wrote in 1992 in the influential international art magazine Flash Art, that these Japanese artists 'mock the Japanese kawai [sic] culture - the cute, vapid Disneyish world of girly taste' (Munroe 1992: 74). Other foreign critics, however, were critical towards the content of kawaii artworks at that time, such as Japan-based art critic Azby Brown, who coined the term 'the Great Tokyo Art Hoax' in the English-language magazine Tokyo Journal. Brown suggested that the media in Japan, together with Japanese and foreign art critics and dealers, promoted young 'brat pack' artists in order to create a lucrative art market. In his view, many young artists did not create challenging and provoking art, but merely produced novelty goods, and he disagreed strongly with Munroe and others, who found the references to kawaii elements to be subversive and critical (Brown 1993).

At the height of the critical concern with kawaii on the Japanese art scene, a number of critics and artists linked the concept to broader political issues such as national identity and the imperial system. In his 1992 article in Bijutsu techô, art critic Sawaragi Noi was highly critical towards mainstream 'cuteness' in contemporary Japanese art. According to Sawaragi, kawaii art is weak and thin, and contains only what he defines as saishôgen no seimei, 'a minimum of life' (Sawaragi 1992: 94). Sawaragi argues that kawaii art, as a subdivision of neo-pop, may function as a protest, especially if kawaii is understood as an antithesis to the lofty and sublime. Other observers, too, have tried to place the concept of kawaii in broader political perspectives, such as the sociologist Ôtsuka Eiji, who relates kawaii to a subcultural nationalism emerging from young Japanese women's grief when the Shôwa Emperor (also known in the West as Emperor Hirohito) passed away in 1989 (Ôtsuka 2003). Within visual arts, Japanese art critic Matsui Midori identifies kawaii in visual arts as a means of defying social systems and thereby overcoming the entrapment of postmodernist simulation art from the early 1990s (Matsui 1996). Art critic Hasegawa Yuko extends the term kawaii by relating it to the concept yôjika (infantilization), and interprets an infantilization of post-war Japanese culture as a system of patriarchal control following the defeat in World War II and the psychological loss of confidence, especially among the Japanese male population (Hasegawa 2002). Murakami Takashi, too, connects the concept of kawaii with national traits 
in the catalogue for the Little Boy exhibition. Cuteness, kawaisa, becomes the core of a pre-child state that Murakami identifies in post-war Japan, linking it to what Murakami sees as a 'culture frozen in its infancy', leaving the Japanese as 'truly, deeply, pampered children. And as pampered children, we throw constant tantrums while enthralled by our own cuteness' (Murakami 2005: 138, 141).

These voices in the Japanese art environment, critical of an unreflected notion of kawaii as a signifier of Japanese culture, contribute to a more nuanced picture of the debates by trying to bring forth elements of various cultural and political tensions within the Japanese society. Overall, the art critics' remarks may, however, appear as an attempt to characterize some kind of essential psychic nature of the Japanese people. As the sociologist Carl Cassegaard points out, Murakami Takashi in particular, but also to a certain degree Sawaragi Noi, draw on nationalist rhetoric while at the same time subverting conventional nationalist discourse. This kind of 'outcaste' or 'underdog' nationalism that Murakami represents is not affiliated at all with right-wing extremism, but, as Cassegaard argues, the rejection of the post-war narrative may end up supporting a more ambiguous type of cultural essentialism that leads to a 'reversed nationalism' (Cassegaard 2010: 54).

\section{The Pink House}

The critical strategies that Sawaragi calls for in his 1992 article can be seen in the artworks by Nishiyama Minako, one of the artists from the 1990s who employs visual elements from kawaii culture to produce complex interrelational dimensions. Throughout her artistic career, Nishiyama Minako has been exploring the issue of pink and kawaii culture, and investigates not only the visual significance but also participatory aspects of kawaii. One of Nishiyama's early works is an installation entitled $\mathrm{Za}$ pinku hausu (the pink house) from 1991 (see Figure 2). The work resembles a three-dimensional bedroom made with plastic elements almost exclusively in pink with pseudo-rococo style of ornamentation. The installation extends from the wall into the gallery space by a rug covering the floor, and the centre part is a large three-dimensional box covered with plastic sheets made to resemble a bed. The plastic bedspread is white with an ornament in the centre, and pink ribbons, rosettes and lace on the sides. The wall has a pattern of pink hearts and dots on a white or light pink background, and several heavy, draped curtains in pink at each side, in front of a two-dimensional image of a window in 
FIGURE 2: Nishiyama Minako, Za pinku hausu (The pink house), 1991

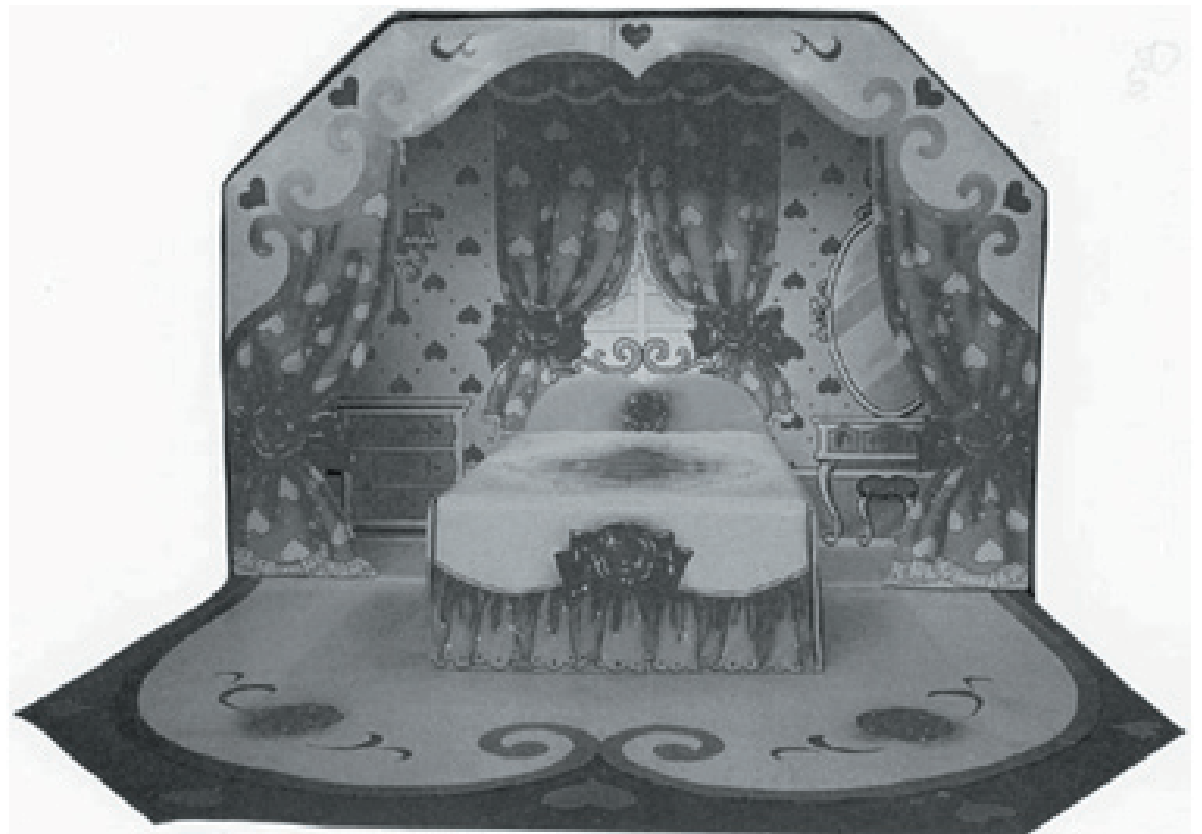

Vinyl cloth, urethane mat, acrylic paint, metal, wall paper, etc., $400 \times 370 \times 280 \mathrm{~cm}$ Reproduced from 10nin no sakka-tachi ga tsuzuru: Ôkina nikki, chiisana monogatari /Private Diary. 10 Japanese Young Artists: Mito Annual 1992. 1992 Mito: Mito Geijutsukan.

the centre. Pieces of furniture are painted on the back wall as well.

The pink rococo-style ornamentation in Nishiyama's installation The Pink House points to another significant kawaii style, that of the cute and sweet in shôjo manga, or girls' comics. From the 1970s onward a number of female manga artists developed stories of romance and love within a distinct kawaii style of flowers, hearts and excessive ornamentation, such as Ikeda Riyoko's Berusaiiyu no bara (the Rose of Versailles), one of the best known manga-narratives from the 1970s (Schodt 1986: 101). Another reference in Nishiyama's work alludes to Rika-chan, a doll character that was invented in Japan in 1967 as a Japanese version of the Barbie doll. The main difference between Rika-chan and Barbie is the physical appearance of the doll related to its age representation: Barbie is significantly portrayed as an adult ideal image of radical proportions, with swelling breasts, pronounced body forms and long legs with feet designed for high-heel shoes. Rika-chan, on the other hand, portrays a teenage girl with a chubby, childlike face and an adolescent body without any bodily signs of adulthood. Rika-chan's face has the signature elements of kawaii appearance in her large eyes, small heart-shaped mouth and diminutive nose. As a toy product, Rika-chan is accompanied by numerous family 
members so as to suggest the values of the nuclear family.

Rika-chan's relationship to middle-class dreams of obtaining a single-family house in the suburbs can be seen in the fold-up plastic house products to be acquired and inhabited by Rika-chan and her friends and family members (Masubuchi 1997). In her artwork, Nishiyama refers not to the Rika-chan doll itself, but to these plastic doll houses, often with a hexagon shape and formed as a suitcase that could be opened and closed for portability. Nishiyama's installation resembles the shape and concept of a Rika-chan doll house produced in human scale. Audiences are invited to enter the installation and interact with the plastic furniture elements, thus performing a cliché fantasy of girlhood dreams by acting in place of the doll and entering an idealized make-believe world. By sizing up the stage-set of many girlhood fantasies, the mechanisms of ideological enchantment through children's cute toys are disclosed and deconstructed.

\section{Sexual Desire and Display}

The bed at the centre of Nishiyama's installation, as well as the pink and cute ornamentation, become a euphemism for one aspect of sexuality, namely dating clubs, escort services and prostitution in the Japanese sex industry. In another work by Nishiyama Minako, a poster design (see Figure 3) entitled Tokimeki Erika no telepon kurabu (Erika's palpitating telephone club) the artist explores the ambiguous juxtaposition of style and subject matter between cute shôjo culture and sexual services. Nishiyama's design mimics pinku bira (pink flyers), small advertisements for 'health clubs' and 'pajama clubs' often pasted on the walls of public telephone booths or handed out by young girls on the streets of red-light districts in urban centres. Many pink flyers during the 1990s (see Figure 4) were designed in pink and pastel colours with illustrations of young women drawn in the style of shôjo manga. The cute and innocent in style and character clashes with the intent of the advertisement in what art critic and curator Hasegawa Yûko has identified as 'an example of terrorism, which highlights the questionable aspects of the sex industry' (Hasegawa 2002: 129). Nishiyama offers an investigation into the visual vocabulary of sexuality on display, in which the cute and innocent not only becomes a dream world FOR the shôjo, but also OF the shôjo. Nishiyama's work reveals the border-lines of desire and the subject position involved by investigating the social codes for a desirable body and the urge to behold and control this body of desire. The divide 
FIGURE 3: Nishiyama Minako, Tokimeki Erika no terepon kurabu (Erika's palpitant telephone club), 1992

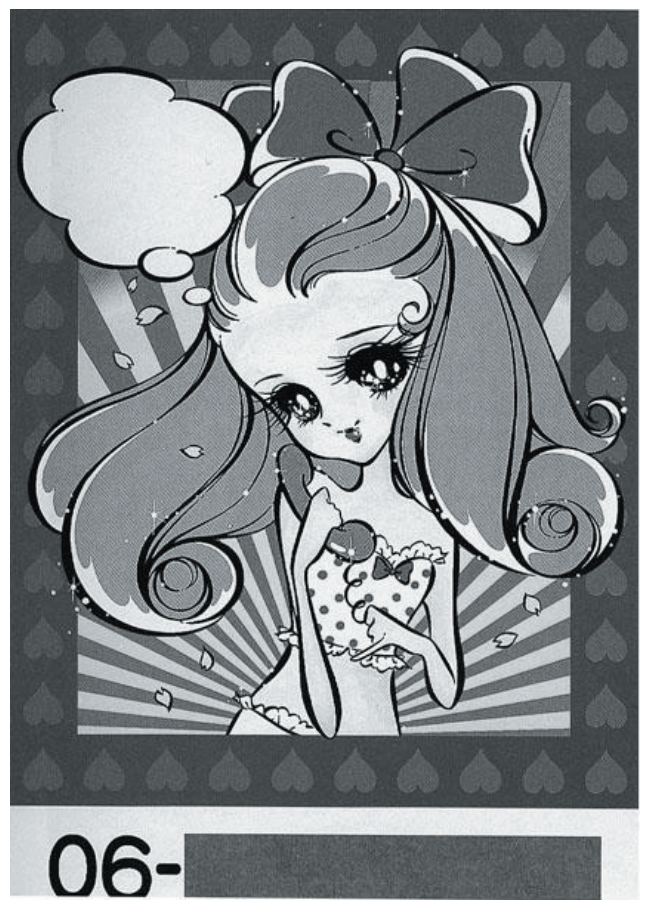

Poster, A2 size. Reproduced from Manga no jidai. Tezuka Osamu kara Evangelion made [The age of manga. From Tezuka Osamu to Evangelion] 1998. Tokyo: Museum of Contemporary Art.

between these two positions is not easily detected in Nishiyama's works, but as Hasegawa continues, Nishiyama's use of kawaii points 'towards a frivolous emptiness, an absence of meaning that pervades the sense of kitsch and cuteness unique to Japan'(Hasegawa 2002: 130). While it is tempting to see Nishiyama's use of kawaii as an ironic feminist position in which the artist dissociates herself from the shôjo culture inherent in her work, it may also be possible to understand Nishiyama's focus on kawaii as a reflection of shôjo ambiguity that surfaced in Japanese mass media during the 1990s concerning the appearance and behaviour of young women in public spaces, to which I shall return shortly.

\section{Performance and Play}

Nishiyama's work The Pink House includes allusions to a theatrical event because of the distinct stage-set appearance and the performative engagement with the audience. The element of theatre emphasizes the aspect of role-playing within the culture of kawaii, not only in the physi- 
cal appearance of the body on stage, but also in the aspect of dressing up and making up the body for display. These tendencies of displaying kawaii fashion on the streets of urban centres in Japan are reflected in the more recent artworks by Sawada Tomoko, whose main project is to display photographic images of herself in various guises. Using computer manipulation of digital photographic images, Sawada has put herself in group photos, school photos, wedding pictures, series of single portrait images and many other genres of portraiture that connect to everyday life and popular culture. In the work School Days/ A (Figure 5), Sawada herself poses as the forty different female high school students as well as their teacher lined up in a photo studio in front of a back drop of the school building and a cherry blossom tree in full bloom. The almost identical faces of all persons involved echo a similarity in the dark blue school uniform that all figures are wearing. Military-style uniforms have been a part of Japanese national identity since the nineteenth century, linked to ideas of modernization as well as tradition in dress codes. Sharon Kinsella points out how female high school uniforms in

FIGURE 4: Pink flyer, 1994

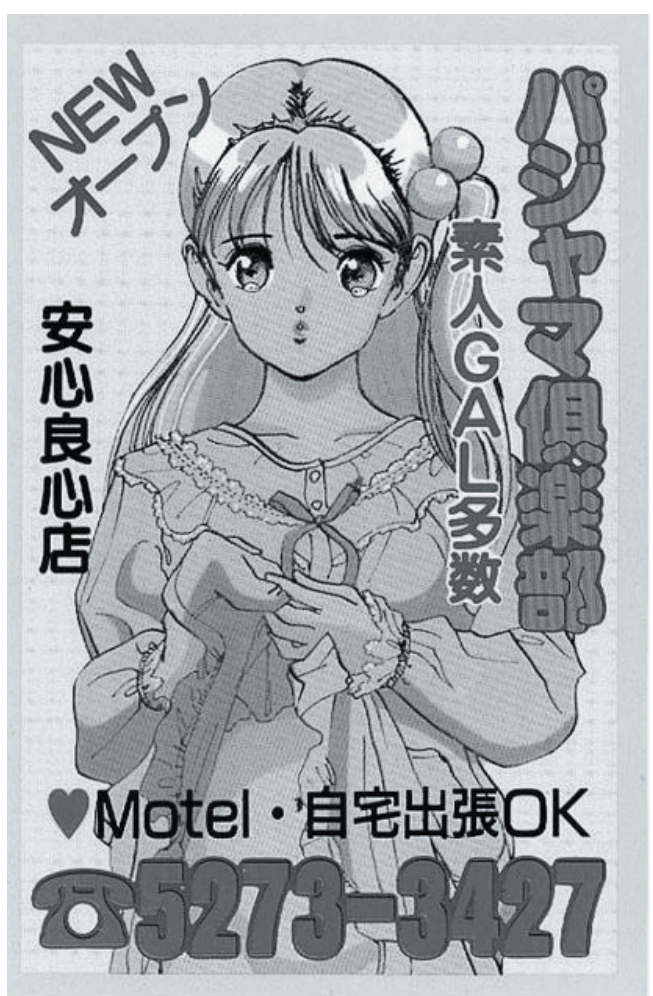

Printed matter, $9 \times 6 \mathrm{~cm}$. Collected by the author in Ikebukuro, Tokyo, 1994 . 
FIGURE 5: Sawada Tomoko, School Days/A, 2004

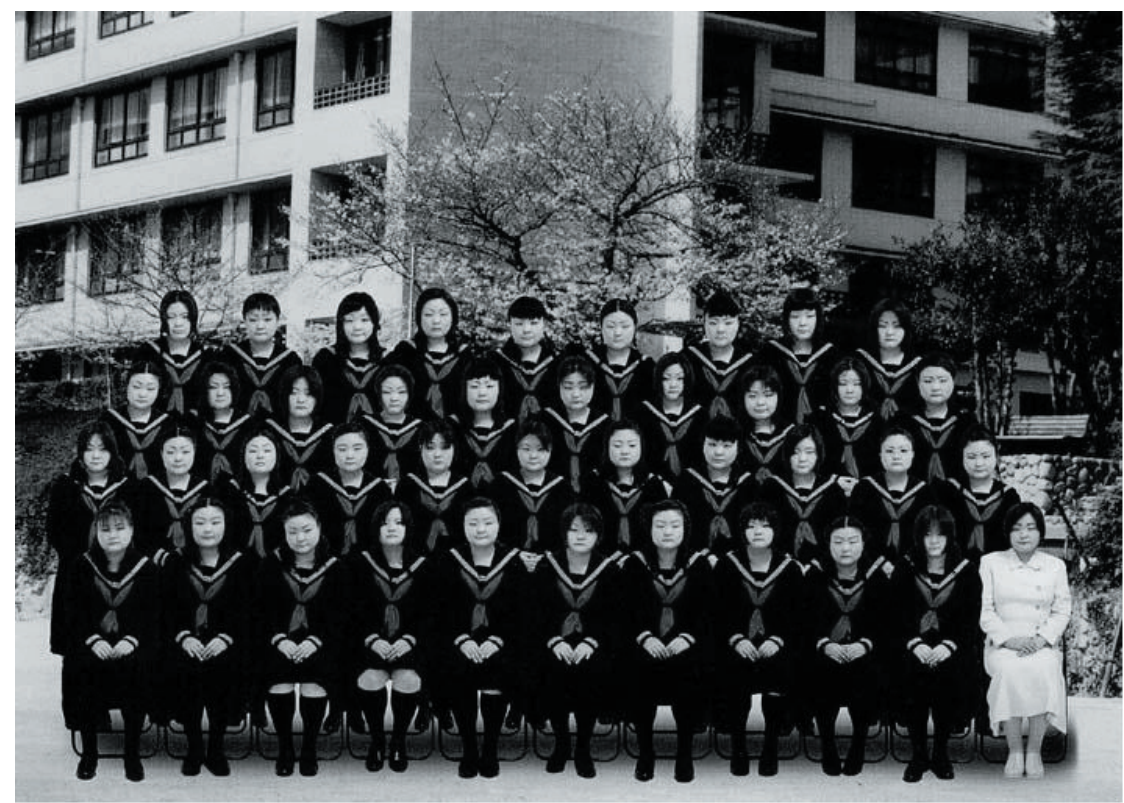

C-type print. Reproduced from Yamaguchi Y. 2007. Warriors of Art. A Guide to Contemporary Japanese Artists. Tokyo: Kodansha International.

particular gained fashion status in the mid-1990s and became central in the so-called kogyaru (high school girl) 'boom'. Media interest in kogyaru, high school girls, included attention to the alleged involvement in new forms of amateur prostitution by high school girls, referred to as enjo kôsai (compensated dating), in which the school uniform came to play a significant visual role in discourses of female sexuality (Kinsella 2002). While the identical faces in Sawada's photos appear as a consequence of the repetition of the model (the artist herself), the use of a generic high school uniform points to the use of uniforms in society in general as a way of homogenizing particular social groups and making visible their social function in the public sphere. As curator Kasahara Michiko notes in her comments on Sawada's School Days series, Sawada portrays a paradox in the behaviour of many school girls in Japan today: 'they want to distinguish themselves from their friends to a certain extent but not enough to stand out from the group' (Kasahara 2009: 48). Although the faces of the figures in Sawada's work display small variations in hair-style and eyebrow shape, the lack of more significant individual differentiation among the faces invites the viewer to reflect upon the way in which certain institutions and their rituals erase the unique and 
personal in favour of standardized appearance.

\section{School Girl Kawaii}

Another work by Sawada Tomoko, entitled Cover (11) from 2002 (Figure 6), relates to similar issues of role-playing and display when Sawada takes the role of two cute-looking girls in casual clothing and fluffy hairstyles. While the official uniform is not apparent in this work, Sawada still points to the concept of uniformizing physical appearance and the way in which group identity is also about dressing and acting like other members in the group to reinforce aspects of bonding and a sense of belonging. The repetition inherent in the figures in Sawada's works points to the aspects of repetition in social roles that form the basis in identity formation.

The performative elements of kawaii in both Nishiyama Minako's and FIGURE 6: Sawada Tomoko, Cover (11), 2002

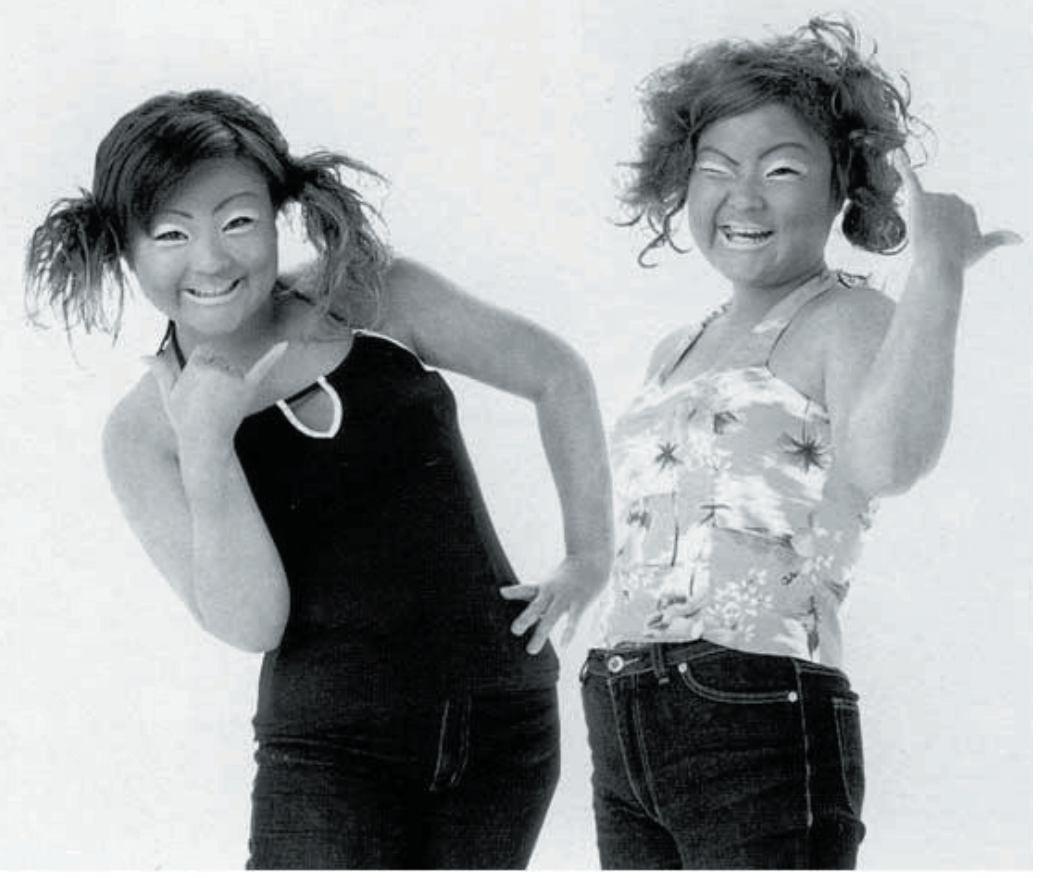

C-type print. Reproduced from Yamaguchi Y. 2007. Warriors of Art. A Guide to Contemporary Japanese Artists. Tokyo: Kodansha International. 
Sawada Tomoko's artworks can be seen as artistic comments on tendencies from the mid-1990s in Japan, where journalists and sociologists started to focus on the social behaviour of cute and sweet girls in public places. The media reported on a number of different styles and youth from different social segments under the generalized and derogatory category of kogyaru, short for kôkôsei gyaru, or high school girl. The media reported how high school girls tampered with their school uniform, for example by folding the waistband to shorten their skirts into miniskirts or using long, thick, white socks that are made to fall down around the ankles. Some girls manipulate buttons or other apparently insignificant details; some girls acquire uniforms from other, more prestigious schools, and some may not even be high school students at all. Sociologist Jennifer Craik notes that while Japanese school uniforms signify discipline, authority and hierarchy, uniforms also embody erotic impulses as fetishized objects (Craik 2005: 225). Sawada Tomoko's mock group portrait of high school girls with grave faces seems to point to the extreme uniformity that is constantly challenged in everyday life. This goes not only for the conformity of clothing, but also the standardized black hair and the apparent lack of emotions in the faces of the figures in Sawada's photo. Kasahara points out that in spite of the many layers of restrictions placed upon Japanese high school girls, Sawada's photographs show the different character of each girl (Kasahara 2009: 48). According to the anthropologist Laura Miller's research on beauty ideals in Japan, a number of real high school girls in the 1990s started bleaching their hair and tanning their faces and would no longer comply with the century-old tradition of women in Japan holding their hand over their mouth when smiling or laughing to not expose their teeth. In the 1990s, young women would flash their white teeth, often made whiter and straighter through expensive processes of so-called dental aesthetics. The innocent and non-sexual school girl was gradually changing into a slimmer and sexier body as the trend of fitness centres and aerobics hit Japan and generated what Miller has identified as a repudiation on the part of the bodiikon gyaru (body-conscious girl), against the previous paedophilic ideal (Miller 2006: 26).

\section{Kawaii as Protest}

The voices of concern or even panic from the media became louder by the late 1990s as the phenomenon of ganguro, or black face, hit the streets of Tokyo. Concerned adults - from parents to school authorities and politicians - worried about what they perceived of as deviant be- 
haviour, rough manners and a deliberately ugly appearance. As Laura Miller and Jan Bardsley wrote in the introduction to the anthology Bad Girls of Japan (2005), women who defy patriarchies draw attention to borders of propriety and invite public debate (2005: 1). The two figures in Sawada's Cover (11) display some of the significant features of ganguro, the dark tanning or painting of the girls' faces, which is contrasted or highlighted by white make-up around the eyes and on the lips. The street provides a space of freedom from school authorities and parents, where high school girls can display the latest fashion fads and still remain anonymous for everyone but their peer group. But through their visibly transgressive trajectory, Miller and Bardsley argue, 'bad girls' are redefined by the media, in which they are either ridiculed or naturalized (Miller and Bardsley 2005: 5). This ganguro-type of girl made headlines in the media because many observers found that these girls made themselves look unattractive and repelling on purpose, with their peculiar make-up and style. According to Sharon Kinsella's analysis of male-centred media, the visual appearance of the kogyaru in general and the ganguro in particular would, among other things, be interpreted in terms of ethnic and indeed racial references because many saw the dark faces as symbolic of 'primitive' peoples or dark-skinned 'southern' races. Ganguro girls were subjected to racist assaults and regarded as a threat to the alleged purity of the Japanese race (Kinsella 2005: 147).

The ambiguity of kawaii in artworks such as those by Nishiyama Minako and Sawada Tomoko discussed above is important exactly because of this ambiguity. The concept of kawaii cannot be ignored as empty or meaningless; as I have argued, kawaii as cultural code regains meaning in the hands of the actual players in the subcultural environments. Since the 1990s, parts of the high school girl population in Japan have declared their distance from the mainstream society by behaving childlike and angry in ways that may annoy others, and thus emulating but also resisting the image of cute and sweet girls. As Laura Miller points out with regards to kogyaru subcultures, 'these youth styles are usually not connected to radical politics, but rather are self-expressions of resistance and rebellion' (Miller 2006: 27). However, the same mechanisms sustain certain norms and values in society by exactly enacting and re-enacting the embodied gestures and signs. The kogyaru and even the ganguro may be subverting certain elements of the expectations of adulthood, but they nevertheless re-enact stereotypes of femininity by highlighting youth, sexually alluring body parts, and lots of make-up. 
This leaves little or no room for performing other versions of embodied gender or escaping binary gender notions altogether.

The girl culture, from which the cute and sweet modes of expression originate, highlights exactly the shôjo, the girl, as a segment of society in a transitional phase from childhood to adulthood. It is tempting, therefore, to see this phase as a point of resistance. Sharon Kinsella concludes from a survey conducted in 1992 that most young people conceive of adulthood as involving responsibility (sekinin) and lack of free time. Kinsella notes that there is no ideal in Japan that links maturity to individual emancipation, and cute lifestyle is seen as a way of acting vulnerable and immature and thus unable to carry out social responsibilities in the family or the work-place (Kinsella 1995: 242-243). Many of the girls indulging in kawaii are deliberately extending the period of shôjo in order NOT to grow up and become shakaijin (a member of society). Girls engaged in such 'derivative' kawaii culture are sometimes blamed in the media for the economic crisis and general misfortunes that Japan has suffered in the so-called 'lost decade' of the 1990s. As Kinsella argues, the journalistic material, although not intentionally dealing with metapolitics, gives the impression of a dangerous female conspiracy against the patriarchal society through a combination of sexual deviance, violence and subcultural nonconformity (Kinsella 2007: 18). Kinsella also notes, however, that the ontological status of 'bad' schoolgirl behaviour, such as enjo kôsai (compensated dating) and terekura (telephone chat lines), has not been established through statistical survey, suggesting that much of the kawaii revolt may in the end be taking place on the front pages of the media rather than in the streets.

\section{Conclusion}

Nevertheless, the concept of kawaii as an image of Japan has dominated the discourse. Japan's Ministry of Foreign Affairs' promotion of three young women as cute cultural ambassadors is a way of embracing kawaii culture on a national level and feminizing the image of Japanese national culture. We can recognize three distinct fashion styles in Figure 1: the pretty-in-pink cute attitude to the left, the kogyaru-style of street fashion in the middle, and the school girl uniform paraphrase to the right. They all refer directly to the main styles flourishing in the streets of Tokyo's youth-centered districts Shibuya and Harajuku, and the three kawaii ambassadors give these styles a face and a body that can now be controlled by official policy and used as a cultural export. Media use 
of categorizations such as kogyaru, including distinct styles visualised and embodied in the three cute ambassadors, may serve as what Laura Miller identifies as 'a vehicle of mainstreaming...cultural power of youth, especially the sub cultural compositions of young women'. Paraphrasing Stuart Hall, Miller notes: 'the media "records" girls' resistance, but then "recuperates" it through labelling and redefinition'(Miller 2006: 30). The official strategy of feminizing and sweetening national identity may be seen as a way of downplaying the social and cultural dynamics of kawaii culture in Japanese society in general.

The codes of appearance and behaviour in the public space of kawaii girl culture depend on inside knowledge to be translated or understood. We can see this kind of ethnographic knowledge manifested in the works by Nishiyama Minako and Sawada Tomoko in that both artists address the ambiguity of kawaii: their artworks expose the dichotomy between the cute and innocent on one hand and the display of Otherness on the other, challenging the idea of a hegemonic national culture. As Sawaragi Noi argued, the paradox of kawaii as 'minimum of life' was connected with the imperial institution and the situation in Japan in general at the key moment of economic and cultural transition at end of the 1980s. Now, two decades later, it seems as if kawaii is reinvented as a soft power tool to boost the Japanese economy in the age of globalization. The attractive aspects of Japanese popular culture have changed from what Iwabuchi Kôichi dubs 'odourless' products and brand names to the current interest in performative and participatory elements.

This is true for kawaii aspects of visual arts produced by Murakami Takashi and his associates as well, despite the many critics who also see resistance and subversion in Murakami's works. Cute and art as the new 'odour' of Japanese culture has joined forces through the promotion of Murakami-related art. Artworks by Murakami and other neo-pop artists appear to a domestic Japanese audience as mu-kokuseki (without nationality), because of these artists' commercial success on the international art market, while the same types of work are being promoted for an international audience as exotically 'Japanese'. The art scene activates the 'marketing boomerang' that other companies within Japan's creative industries have used successfully in the first decade of the twenty-first century.

So when official Japan now seems to be embracing and even exporting aspects of kawaii, my analysis is that it is a strategy to gain control of the subversive. By assimilating and mainstreaming the culture of kawaii and furthermore exporting kawaii out of its original context, specific socio-po- 
litical aspects get lost or transformed into something else. In this process of flattening the depths of critical encounters and softening the sharpness of subversive resistance, the social critique inherent in kawaii culture thus becomes silenced. The potential for disclosing social issues through visual arts in contemporary Japan lies in the performative and participatory aspects inherent in popular culture in general, and addressed in artistic practice by a number of committed artists on the Japanese art scene.

Gunhild Borggreen is Assistant Professor, Department of Arts and Cultural Studies, University of Copenhagen. She is currently working on visual culture related to robots in Japan.

\section{NOTES}

1. All names are given in the Japanese order with last name preceding given name.

2. To mention some examples: the Superflat exhibition trilogy curated by Murakami Takashi, including the show Little Boy. The Arts of Japan's Exploding Subculture at the Japan Society in New York, 2005; the exhibition My reality - contemporary art and the culture of Japanese animation at Des Moines Art Center, 2001; the touring exhibition Girls don't cry, curated by Nanjo and Associates from Tokyo; the exhibition Neoteny Japan. Contemporary Artists After 1990s - From Takahashi Collection in 2008; and the show Winter Garden: The Exploration of the Micropop Imagination in Contemporary Japanese Art, The Japan Foundation Traveling Exhibition in 2009.

\section{REFERENCES}

Allison, A. 2008. 'The Attractions of the J-Wave for American Youth'. In Soft Power Superpowers: Cultural and National Assets of Japan and the United States, edited by Watanabe Y. and D. L. McConnell, 99-110. Armonk, NY: M.E. Sharpe.

Brown, A. 1993. 'The Great Tokyo Art Hoax'. Tokyo Journal 9: 26-33.

Cassegaard, C. 2010. 'Japan's Lost Decade and Its Two Recoveries. On Sawaragi Noi, Japanese Neo-Pop and Anti-war Activism'. In Perversion and Modern Japan: Psychoanalysis, Literature, Culture, edited by N. Cornyetz and J. K. Vincent, 39-59. London: Routledge.

Craik, J. 2005. Uniforms Exposed: From Conformity to Transgression. Oxford: Berg.

Enomoto R. and K. Matsuoka. 1986. 'Ima kakeru onna' [Women advancing now]. Bijutsu techô [Art notes] 38(566): 46-59.

Frederick J. 2003. 'Move Over, Andy Warhol'. Time Magazine, May 19: 60-61.

Hasegawa Y. 2002. 'Post-identity Kawaii: Commerce, Gender and Contemporary Japanese Art'. In Consuming Bodies. Sex and Contemporary Japanese Art, edited by F. Lloyd, 127-141. London: Reaktion Books.

Iwabuchi, K. 1998. 'Marketing "Japan": Japanese Cultural Presence under a Global Gaze'. Japanese Studies 18(2): 165-180.

Iwabuchi, K. 2002. Recentering Globalization. Popular Culture and Japanese Transnationalism. Durham: Duke University Press. 
Kasahara, M. 2009. 'Gender Issues in Japanese Contemporary Photography'. In PostGender: Gender, Sexuality and Performativity in Japanese Culture, edited by A. Zohar, 40-49. Newcastle upon Tyne: Cambridge Scholars Publishing.

Kinsella, S. 1995. 'Cuties in Japan'. In Women, Media and Consumption in Japan, edited by L. Skov and B. Moeran, 220-254. Honolulu: University of Hawaii Press.

Kinsella, S. 2002. 'What's Behind the Fetishism of Japanese School Uniforms?' Fashion Theory 6(2): 215-237.

Kinsella, S. 2005. 'Black Faces, Witches, and Racism against Girls'. In Bad Girls of Japan, edited by L. Miller and J. Bardsley, 142-157. Basingstoke: Palgrave Macmillan.

Kinsella, S. 2007. 'Female Revolt in Male Cultural Imagination in Contemporary Japan'. In The Fourth Chino Kaori Memorial 'New Visions' Lecture. Kyoto: Medieval Japanese Studies Institute.

MadameGinerva 2009. 'Misako' Available from: http://www.youtube.com/watch?v= NR8SsqWKJ1c\&feature=related [accessed 3 May 2010].

Masubuchi S. 1997. 'Rika-chan to Rika-chan hausu' [Rika-chan and Rika-chan House]. In Rika-chan hausu no hakurankai. Maihômu doriimu no hensen [Rika-chan house exhibition. Changes in the 'my-home' dream]. Tokyo: Inax Shuppan.

Matsui M. 1996. 'Hen' ai no maikuroporitikusu. Itsudatsu no shingô to shite no 'kawairashisa' ' [The micropolitics of partiality. 'Cuteness' as a symbol of deviance]. Bijutsu techô [Art notes] 48(720): 25-41.

McGray, D. 2002. 'Japan's Gross National Cool'. Foreign Policy May/June 2002: 44-54.

Miller, L. 2006. Beauty Up. Exploring Contemporary Japanese Body Aesthetics. Berkeley: University of California Press.

Miller, L. and J. Bardsley. 2005. 'Introduction'. In Bad Girls of Japan, edited by L. Miller and J. Bardsley, 1-13. Basingstoke: Palgrave Macmillan.

Ministry of Foreign Affairs (Japan) 2009. 'Commission of Trend Communicators of Japanese Pop Culture in the Field of Fashion'. Available from: http:/www.mofa. go.jp/announce/event/2009/2/1188515_1152.html [accessed 27 April 2009].

Munroe, A. 1992. 'Wandering Position. Conceptual Art in the Post-Hirohito Era'. Flash Art 25(163): 74.

Murakami T., ed. 2005. Little Boy. The Arts of Japan's Exploding Subculture. New York: Japan Society.

Nakano O. 1988. 'A Sociological Analysis of the New Breed'. Japan Echo 15: 12-16.

Ôtsuka E. 2003. Shôjotachi no kawaii tennô. Sabukaruchaa tennôron [Girls' cute emperor. Theories of the emperor in subculture]. Tokyo: Kadokawa bunsho.

Robertson, R. 1997. 'Glocalization: Time-Space and Homogeneity-Heterogeneity'. In Global Modernities, edited by M. Featherstone, S. Lash and R. Robertson, 25-44. London: Sage.

Sawaragi Noi 1992. 'Rori poppu - sono saishôgen no seimei' [Lollipop - a minimum of life]. Bijutsu techô [Art notes] 44(651): 86-98.

Schodt, F.L. 1986. Manga! Manga! The World of Japanese Comics. Tokyo: Kodansha International.

Shatteredlolita. 2009. 'You just have to love the gothic lolita fashion'. Available from: http://www.youtube.com/watch?v=6aTQ525R0aM [accessed 3 May 2010].

Toonleap. 2009. 'March 12, 2009'. Available from: http://www.cartoonleap. com/2009/03/12/japan\%C2\%B4s-ambassadors-of-moe-and-kawaii/ [accessed 14 July 2009].

Yamaguchi Y. 2004. Cool Japan. Shissô suru Nihon gendai aato / The exploding Japanese contemporary art. Tokyo: BNN Shinsha.

Yamaguchi Y. 2007. Warriors of Art. A Guide to Contemporary Japanese Artists. Tokyo: Kodansha International. 